局所陰圧療法と植皮術によって完治した壊死性筋膜炎の 1 例

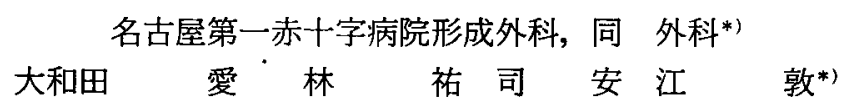

症例は63歳，男性. 背部の激しい疼痛を主訴に当院へ搬送された。著明な局所炎症所 見, 血液生化学検査結果, CT 所見, 切開時に認めた筋膜を含む皮下組織の広範な壊死像 などから壊死性筋膜炎と診断した，未治療の糖尿病，高龄，体幹部を発症とすることな ど重症化する要因を備えていたが，早期の広範囲デブリードマンによって救命できた。 術後は背部に深いポケットを伴う皮膚欠損が生じたため, 局所陰圧療法を行った。大き なポケットは完全に閉鎖され，わずかな植皮のみで皮周欠損を再建できた.

本症は早期診断，早期デブリードマンによって救命した後も，ポケットを伴う広範な 皮傎欠損の創管理，再建に難渋することが多い. 術後は開放創として管理することが原 則となっているが, 急性炎症期を乗り切った後は, 局所陰圧療法によって閉銷創として 管理することも有用と思われた。

索引用語：壊死性筋膜炎, 局所陰圧療法, topical negative-pressure therapy

\section{緒言}

壊死性筋膜炎は，真皮から浅在性筋膜に至る皮下組 織が急速に壊死に宿る皮虔感染症で，直ちにデフリー ドマンなどの適切な㚮置を行わなければ死に至ること もある重篤な疾患である．また救命後も広範な皮膚欠 損を残し，再建に苦慮することも多い．わ机わ机は背 部の壊死性筋膜炎に対し頻回のデブリードマンを行 い，術後大きなポケットを伴う皮虐欠損を残した症例 に対して局所陰圧療法を行い，最終的にわずかな植皮 のみで完治した 1 例を経験したので報告する。

$$
\text { 症例 }
$$

症例：63歳, 男性.

主訴: 背部痛.

既往歴：未治療の糖尿病。

現病歴：2005年 7 月初旬に背部に痛みを感し，粉瘤 の感染と思われる皮席病変を自覚したが放置してい た，痛みが継続したため中旬に近医を受診し，抗生剤 の点滴を受けた。下旬に激しい痛みを自覚し，再び近 医を受診したところ同部位に広範な炎症所見を認めた ため, 当院救急部へ搬送された。

2006年 2 月 2 日受付 2006年 2 月27日採用 〈所属施設住所〉

于453-8511 名古屋市中村区道下町 3-35
入院時所見: 背部全体に発赤, 腫脹が広がり, 水疮 が散在していた。発赤部に一致して強い疼痛を認めた。 血液生化学検查所見：WBC $27,700 / \mu 1, \mathrm{RBC}$ $4.21 \times 10^{6} / \mu \mathrm{l}, \mathrm{Hb} 13.4 \mathrm{~g} / \mathrm{dl}, \mathrm{Ht} 39.7 \%$, Plt $36.3 \times 10^{4} /$ $\mathrm{mm}^{3}$, CRP $30.2 \mathrm{mg} / \mathrm{dl}$, AST 16IU/l, ALT 23IU/1, LDH $334 \mathrm{IU} / \mathrm{l}, \mathrm{BUN} 17 \mathrm{mg} / \mathrm{dl}, \mathrm{Cr} 0.7 \mathrm{mg} / \mathrm{dl}$, 随時血 糖 $748 \mathrm{mg} / \mathrm{dl}, \mathrm{HbAlC13.1 \% .}$

胸腹部 CT：皮膚は肥厚し，背部皮下組織は著明に 腫脹していた（図 1 )。

入院後臨床経過：当院搬送後ドレナージを行い入院 となった(図 $2 \mathbf{a})$. 今回初めて糖尿病を指摘され，イ ンスリン療法による血糖コントロールが開始された. 炎症がさらに進行したため, 入院後 2 日目に局所麻酔 下, 3 日目には全身麻醉下でデブリードマンを行った。 術中所見では，皮下組織は筋層を含めて広範に壊死に 陷っており，米のとぎ汁様排液と一部皮膚壊死を認め た.これらの所見より壊死性筋膜炎と診断した。細菌 培養検査で検出されたのは Staphylococcus aureus の みであった.デブリードマン後は切開創の周囲に $6 \mathrm{~cm}$ から $12 \mathrm{~cm}$ の幅で皮下ポケットが形成された（図 2 b). 翌日から洗浄, 適宜デブリードマンを追加し, 残 存した壊死組織を除去した。血液生化学検查にて炎症 所見は順調に軽減し, 肉眼的にも徐々に創の清浄化が 図られたため,トラフェルミン(フィブラストスプレ 


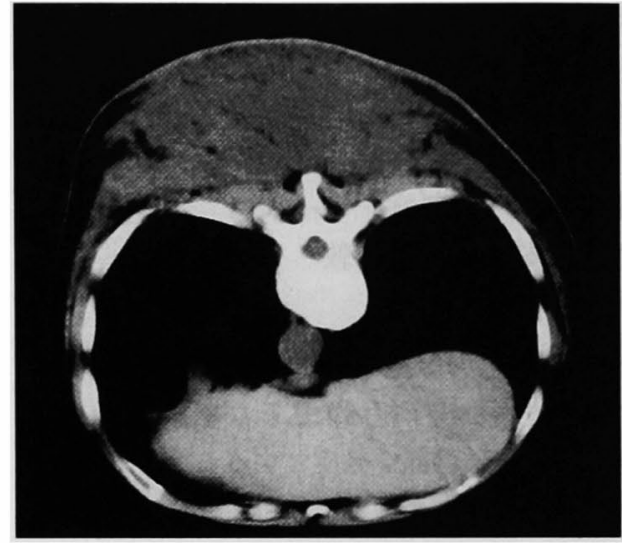

図 1 入院時腹臥位 CT: 背部皮風の肥厚と皮下 組織の著明な腫脹を認めた。筋膜は融解し, 壊死 性筋膜炎が疑われた。

一)を外用して肉芽形成を促進させた. 術後18日目の 皮膚欠損の大きさは約 $25 \mathrm{~cm} \times 15 \mathrm{~cm}$ で周囲に $4 \mathrm{~cm}$ か ら $9 \mathrm{~cm}$ の幅で皮下ポケットを認めた（图 $2 \mathrm{c}$ ). 壊死 性筋膜炎では, 感染に沿ってデブリードマンを進めて いくと, 皮下ポケットの辺縁は先細りの形状をとるこ とがある. 自験例でも, ポケットの辺縁は一部媣く細 く皮下を這い, 複雑な形状をしていた. 死腔を残すこ となくポケット全体を閉じる目的で，局所陰圧療法を 開始した，処置は創洗浄後にトラフェルミンをポケッ 卜内へ噴霧し, 創面に15Fr の J-VACドレナージシス テム® (ジョンソンエンドジョンソン) を留置しアイ オバンスペシャルインサイズドレープ (3M) を用い た閉鎖ドレッシングを行った(図 $3 \mathrm{a}$ )，渗出液の量は 徐々に減少し(図 4), 局所陰圧療法開始後25日目にポ ケットは完全に閉鎖され，皮属欠損は約 $12 \mathrm{~cm}-8 \mathrm{~cm}$ まで縮小した。開始後35日目に分層網状植皮術を行い, その 1 週間後に完治と診断し, 入院後79日目に退院と なった（図 3 b).

\section{考 察}

本症は急激に進行し, 死亡する可能性が高い疾患で ある。早期デブリードマンや積極的な輸液療法, 血液 浄化療法などにより救命された報告を散見する が(1) 死亡率は $20.3 \%^{4}, 30 \%{ }^{51}, 37.5 \%$ と依然高い.さらに 糖尿病合併例では重症化しやすく778), 諸家の報告によ 万死亡率は $33.3 \%$ (非合併例 $4.5 \%$ ) ${ }^{91}, 50 \%$ (非合併例 $21.6 \%)^{10)}$ と非合併例に比へて高い。また発生部位は下 肢に多く体幹部を初発とすることは稀で，その予後は
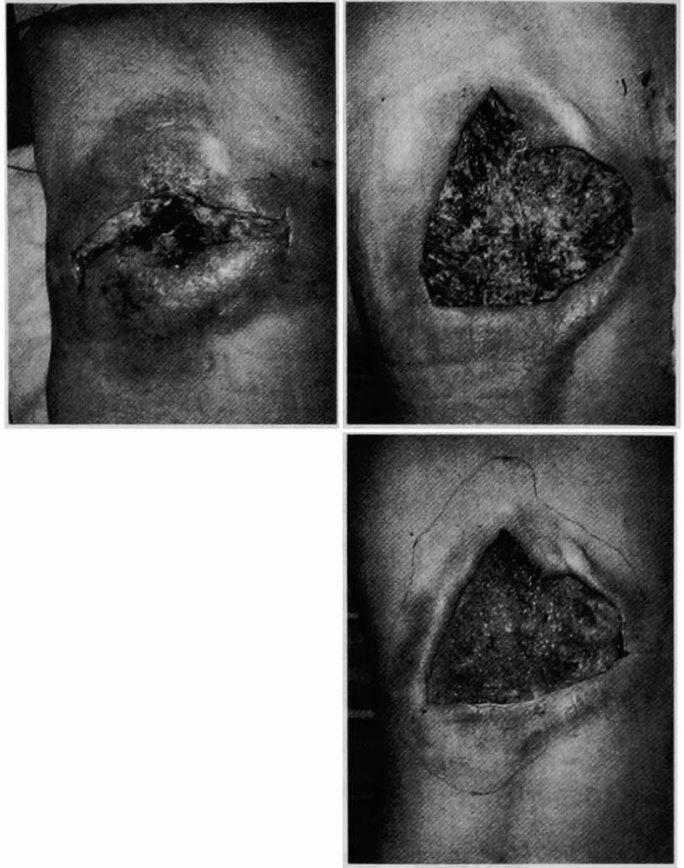

図 2 創部の臨床経過 ( 1 )

a 初回ドレナージ施行時: 皮下組織の広範な罗死 を認めた。

b 全身麻酔下でのデフリリードマン直後：広背筋の 一部を含めてデブリードマンを行った。

c 局所陰圧療法開始時：ポケット内には不良肉芽 が残存し，ポケット辺縁は一部深く細く皮下を這って いた。創周囲の実線はポケットの概形を示す. $\frac{\mathrm{a}}{\mathrm{a}} \mathrm{b}$

一般に不良とされる ${ }^{11)}$. 自験例は63歳と高龄で5), 未治 療の糖尿病を合併し体幹部を初発とするなど，重症化 する要因を有していたが，早期に広範なデブリードマ ンを行ったことで良好な経過をたどることができた. 本症は初期の段階では診断が困難なことも多く，結果 的に病態が進行してから広範囲デブリードマンを要す

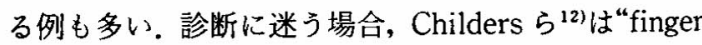
test", 神谷 ${ }^{13)}$ は multiple skin incision と呼ばれる試験 切開を行い直視下に筋膜を観察し，同時に標本を採取 し診断することを勧めている．治療法は早急なデブリ 一ドマンと抗生剤の大量投与が原則であり, 感染が落 ち着いた後は創部の再建が必要となる. 本症は深在性 筋膜や筋層にまで感染が及ぶことも稀ではなく, デブ リードマン後は皮膚欠損とともに染く大きなポケット が形成されることも多い.早川ら ${ }^{14)}$ は超音波入スを用 いて皮下ポケット内の不良肉芽をデブリードマンし， 


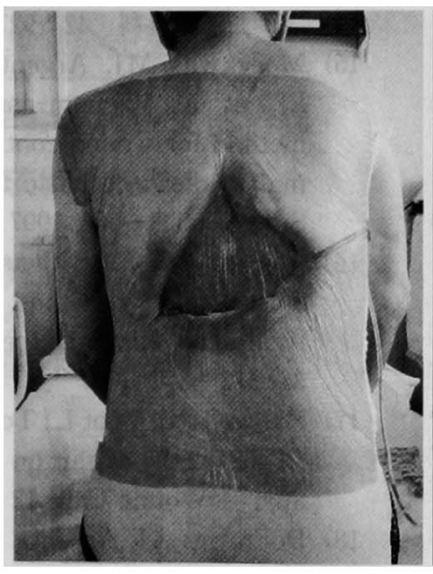

a

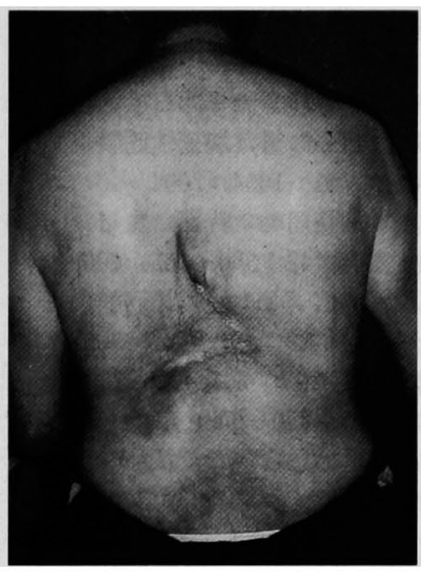

b

図 3 創部の臨床释過（2）

a 局所陰圧療法施行時

b 植皮術後 3 週間目（退院時）：合併症なく社会復帰した.

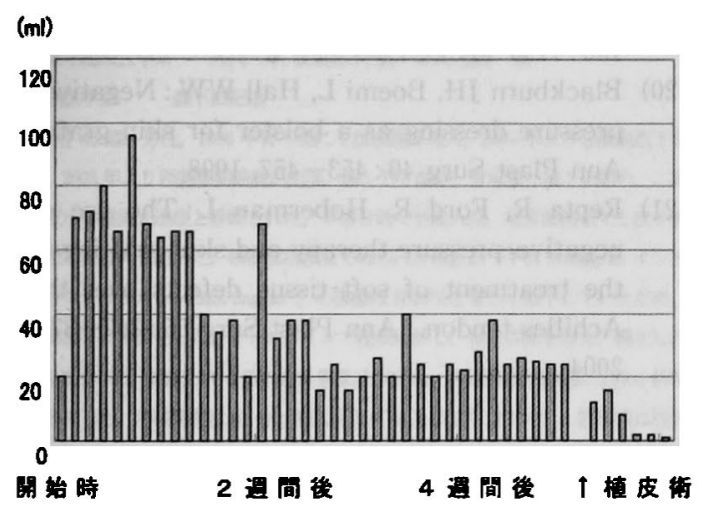

図 4 局所陰圧療法期間中の 1 日窑出液量

tie over をかけて一期的に再建し良好な結果を得たこ とを報告している，自験例もデブリードマン後，巨大 ポケットの処理を要した。われわれは, トラフェルミ ンを外用しながら局所陰圧療法によるポケット閉鎖を 試みた。局所陰圧療法は難治性潰瘍の治療方法として 1997年に Argenta と Morykwas ら ${ }^{15) 16} に よ っ て$ 紹介 されて以来, 近年創傷治疮の分野で広まっており，欧 米では VAC 療法 (vacuum-assisted closure therapy) として普及している.これは創部に一 $50 \mathrm{mmHg}$ からー $125 \mathrm{mmHg}$ の陰圧を持続的または間歇的にかけるドレ ッシング法で, 吸引ポンプ，チューブ, 創部に設置す るスポンジ，ドレープが一式で製品化されている，本 邦にはVACが導入されていないため, 施設ごとに入
手可能な機材を組み合わせて局所陰圧療法を行ってい るのが現状である．本法の長所として，非侵襲的で簡 便な手技で開放創を閉鎖創に変換させること, 創床か ら涰出液を効果的に取り除きつつ創傷治疮に重要な湿 潤環境を維持すること, 浮腫を軽隇させること, 細菌 数を減らし感染を制御すること, 創への血流を増加さ せ血管新生を促進させること, 軟部組織を移動させ皮

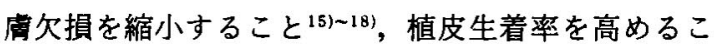

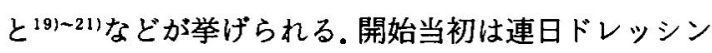
グを交換したが, 間もなく 4,5 日に 1 回程度のドレ ッシング交換で創管理が可能になった．植皮片と創床 との密着を保ち, 剪断力を軽減させる ${ }^{(9)-211}$ 目的で植皮 術後も局所陰圧療法を継続し，植皮は完全生着した。 本症の上うな重症感染症後の不良肉芽が残存する皮虙 欠損で，なおかつ栯尿病を合併する症例に対しても， 局所陰压療法は有用と考えられた。

\section{結 語}

壊死性筋膜炎の 1 例を早急なデブリードマンによっ て救命した、術後に皮下ポケットを伴う広範な皮虚欠 損を残したが，局所陰圧療法によってこれを閉鎖し， わずかな植皮のみで大きな皮用欠損を再建することが できた.

\section{文 献}

1）阿部紘一郎, 的場保巳, 森 正夫他：体幹部の広 範な壊死性筋膜炎て哭症した劇症型溶連菌感染症 の 1 救命例. 日臨外会誌 $66: 322-326,2005$ 
2）寺尾友宏，庄司豊彦，三浦信義 他：壊死性筋膜炎 の 6 例. 整災外 $46: 253-257,2003$

3）吉野公二，新見やよい，小坂祥子他：即日広範围 デブリードマンを施行し救命し得た壇死性筋膜炎 の 1 例. 皮苚臨床 46:1651-1654, 2004

4）松下明子, 木村太紀，本田隆司 他：背部に生じた 壊死性筋膜炎の 1 例. 皮庙 $42: 360-363,2000$

5）石黒匡史，山下理恵，橋本信子 他：壊死性筋膜炎 の臨床学的検討. 日形会誌 $22: 421-427,2002$

6）宮本正，東原信七郎，小野勝之他：壊死性筋膜炎 の治療成績. 整形外科 $55: 650-653,2004$

7）林悟, 武田義敬：糖尿病に合併した壊疽性筋 膜炎の 3 例。日臨外会誌 $65: 833-836,2004$

8) Nai-Chen Chen, Hao-Chi Tai, Yuen-Bih Tang : Necrotising fasciitis : clinical features in patients with liver cirrhosis. Br J Plast Surg $58: 702-707,2005$

9）大谷晶子, 高井和子, 山崎美由紀他：壊死性筋膜 炎の 2 例。皮店 $34: 593-598,1992$

10）中西加寿也, 平澤博之, 渡辺栄三他：壊死性筋膜 炎. Curr Concept Infect Dis 8:15-17，1999

11）嶋津岳士, 樢飼勲, 角由佳 他：グラフ救急領域の CT 画像壊死性軟部組織感染症. 外科治療 $91: 707-719,2004$

12) Childers BJ, Potyondy LD, Nachreiner R, et al : Necrotising fasciitis: a fourteen-year retrospective study of 163 consecutive patients. Am Surgeon $68: 109-116,2002$

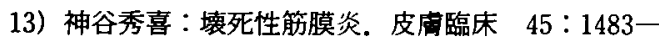
1488,2003

14）早川治，角谷徳芳，伊藤芳憲他：壞死性筋膜炎の
3 例. 形成外科 $42: 927-931,1999$

15) Morykwas MJ, Argenta LC, Shelton-Brown EI, et al: Vacuum-assisted closure: a new method for wound control and treatment : animal studies and basic foundation. Ann Plast Surg 38:553-562, 1997

16) Argenta LC, Morykwas MJ : Vacuum-assisted closure: a new method for wound control and treatment : clinical experience. Ann Plast Surg $38: 563-577,1997$

17) Banwell PE, Teot $L$ : Topical negative pressure (TNP) : the evolution of a novel wound therapy. J Wound Care $12: 22-28,2003$

18) DeFranzo AJ, Argenta LC, Marks MW, et al : The use of vacuum-assisted closure therapy for the treatment of lower extremity wounds with exposed bone. Plast Reconstr Surg 108 : 11841191,2001

19) Schneider AM, Morykwas MJ, Argenta LC : A new and reliable method of securing skin grafts to difficult recipient bed. Plas Reconstr Surg $102: 1195-1198,1998$

20) Blackburn JH, Boemi L, Hall WW : Negativepressure dressing as a bolster for skin grafts. Ann Plast Surg 40:453-457, 1998

21) Repta R, Ford R, Hoberman L: The use of negative-pressure therapy and skin grafting in the treatment of soft-tissue defects over the Achilles tendon. Ann Plast Surg $55: 367-370$, 2004

\title{
SUCCESSFUL TREATMENT OF NECROTIZING FASCIITIS USING TOPICAL NEGATIVE-PRESSURE THERAPY AND SKIN GRAFTING AFTER AGRESSIVE DEBRIDEMENT
}

\author{
Ai OWADA, Yuji HAYASHI and Atsushi YASUE*) \\ Departments of Plastic and Reconstructive Surgery and Surgery*1 \\ Japanese Red Cross Nagoya First Hospital
}

Necrotizing fasciitis is a life-threatening soft tissue infection with a high mortality rate. After saving a patient, a large skin defect with a pocket is usually left that is difficult to close. We report a case of necrotizing fasciitis in the back. A 63-year-old man with uncontrolled diabetes mellitus was brought to our hospital because of severe back pain. There was exudative erythema with blisters on his back. Emergent surgical debridement was performed, and we diagnosed his illness as necrotizing fasciitis from the intraoperative findings. After debridement, a large skin defect with a deep pocket was left. We successfully closed the pocket and prepared a wound bed for replacement of a split-thickness skin graft using topical negative-pressure therapy in the preoperative period and also used it as a dressing to allow skin grafting. Although it is common to have a wound of necrotizing fasciitis open after debridement, it seems that topical negative-pressure therapy can close a pocket and improve the potential for healing such problem wounds. 